\title{
Legens. Ambiguity, Syllepsis and Allegory in Claudian's De Raptu Proserpinae
}

\begin{abstract}
The De Raptu Proserpinae is widely seen as the high point of Claudian's classicism. In my discussion, however, I observe this poem from a different perspective, leaving aside questions of the poem's classical models and instead concentrating on its exquisitely late antique allegorical potential. My main argument is that the praefatio performs allegory through a powerful syllepsis located at its very center (legens, v. 6): it represents an invitation to read allegorically. I suggest that this famous praefatio, generally taken to refer to Claudian's own poetic career, is instead an allegory of reading, which is always unavoidably ambiguous, and that within the preface ambiguity itself reaches its apex through the syllepsis legens. ${ }^{1}$
\end{abstract}

Keywords: epic poetry, late antiquity, allegory, allegoresis, syllepsis, Claudian, interruption

Ambiguity is not only a feature characterizing certain texts, but it can be defined as the primary way of functioning of any text belonging to any historical period and literary genre. A text is always ambiguous, not so much because its author intentionally wanted it to be so, but more compellingly because the meaning produced by each reader is always a result of the constitutive semantic instability of the written words. Moreover, whatever the meaning might be that the author intentionally attached to his or her text, the text itself always turns away from it, so that readers are confronted with an unavoidable and always recurring ambiguity: between the intention of the author and the meaning produced by the readers' own interpretation. But, if ambiguity and literature are by definition intertwined, allegory and allegoresis - more than any other generic or hermeneutic discourse - make ambiguity their ruling principle, since in an allegory or an allegorical interpretation (allegoresis) the literal meaning always adumbrates that

1 I would like to express my deep gratitude to the editors of this volume: Therese Fuhrer, Martin Vöhler and Stavros Frangoulidis. Paolo Felice Sacchi gave me, as always, very valuable suggestions. While preparing this paper for publication I had the opportunity to discuss Claudian's epic poem with the students in my Master's seminar on late Latin poetics at Ghent University. I thank them all, and in particular Seppe De Craemere, for their astute comments and passionate readings. 
other meaning which at the same time is located in and transcends the text. Late antiquity no doubt represents the golden age of allegory and allegoresis, not so much because authors intentionally produce allegories in the proper sense (as for example with Prudentius' Psychomachia) but rather because allegoresis pervasively affects the reading of many texts of this period.

In the following discussion I draw attention to one of the most ambiguous texts of late Latin poetry, which in my opinion has been the object of critical distortion precisely because its modern interpreters see in its inherent ambiguity an obstacle to the comprehension of the text, instead of productively making sense of it (Praef. 1.1-12):

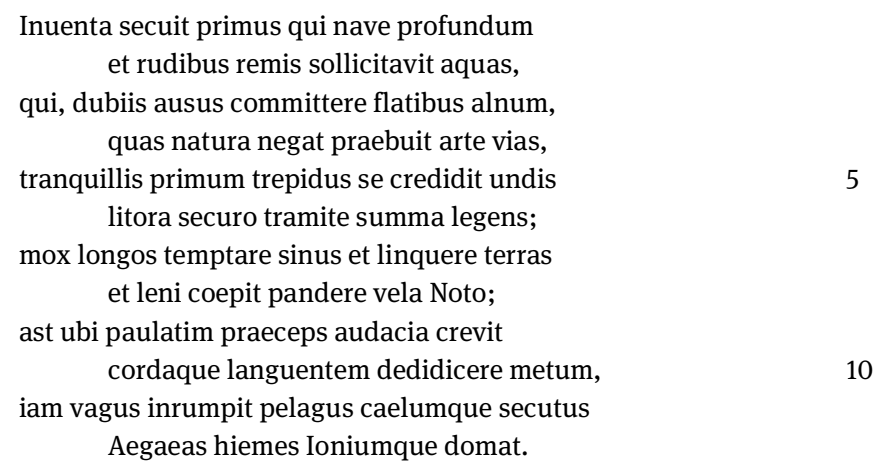

He who first cut the deep with the ship he had invented, and disturbed the waters with rough-hewn oars, who dared to commit his vessel of alder-wood to the unreliable blasts and made available by his art ways which nature denies, at first trusted himself trembling to the calm waves, coasting along the edge of the shores on a safe course; soon he began to try out vast bays, to leave the land and spread his sails to the mild south wind; but when, little by little, his impetuous boldness grew and his heart forgot sluggish fear, roving now far and wide he burst upon open water, and, following the sky, mastered Aegean storms and the Ionian Sea. ${ }^{2}$

There is a man, the first who decides to cross the sea on a boat. Gradually, after having trained himself in controlling nature through his technique, and having unlearned his fear, this man leaves the coast and with his boat finally reaches the open sea. This is the very simple content of the preface to the first book of the $D e$ Raptu Proserpinae by Claudian, written between the end of the 4th and the early 5th century, consisting of three books; a fourth, final book, containing the last

2 I follow the text of Charlet 1991 and give the English translation of Gruzelier 1993. 
part of the myth, i.e. Ceres' reconciliation and the consequent distribution of grain, was probably never written. ${ }^{3}$

If we only consider this brief but elegantly constructed prefatory poem ${ }^{4}$ and its content, not much meaning emerges from this apparently banal narration. The most intriguing aspect is that no explicit or implicit connection is established with the epic poem itself or its content, i.e. the myth of Proserpina's abduction, so that this preface can quite perfectly be read in isolation or, better put, it could be attached to virtually any other text. In formal terms, too, its meter marks its independence from the epic proper, since, like the preface to the second book, it is in elegiac couplets.

But how can readers make sense of this preface? What could its meaning or meanings be, both per se and considered with the epic poem itself? Undoubtedly readers are implicitly invited to interpret this carmen as the "threshold" to the subsequent mythological epic, and yet the author does not provide any kind of instruction on how to connect it to the epic proper. We do not find, for instance, any hint of a comparison between the unnamed sailor and the poet, or any other mythical sailors. ${ }^{5}$ Of course, while reading of a person who undertakes for the first time a journey on the sea within a classically crafted little Latin poem our memory almost unavoidably brings us to the first sailor of Greek myth, Jason, and the saga of the Argonauts. ${ }^{6}$

As always seems to happen as soon as a text presents itself as ambiguous or difficult to interpret, scholars' reaction is diverted from the text itself to the author's intentions - in other words, the question becomes "Whatever did the author want to say?" instead of "What does this text mean?" Instead of appreciating and interpreting ambiguity as such, critics pertinaciously try to solve it, as if the aporia of meaning deriving from the ambiguous text simply represented a provocation

3 See Charlet 1991, XXXVIII. Schottenius Cullhed 2019, 83-84 offers a concise overview of various speculations advanced by scholars and possible interpretations.

4 Felgentreu 1999, 163 speaks of a "knappe, dichte, strenge Form”.

5 An anonymous copyist of a now lost manuscript of Sankt-Gallen tried to fill what for him was a gap in the meaning by adding to the end of Claudian's text a reassuring final element revealing the supposed comparison: sic ego qui rudibus scripsi praeludia verbis / ingredior Stygi nobili Ditis opus. See Felgentreu 1999, 161.

6 See Felgentreu 1999, 156-167, Charlet 1991, 4-5 (who provides a list of parallels from Horace to Martial) and Harrison 2017 (who comments that "the invention of the ship mentioned by Claudian irresistibly recalls the story of the Argonauts" [240, emphasis mine]). 
launched by the author to his readers in order for them to exercise their detective skills. $^{7}$

But this shift of attention from the text to its author is fatal for interpretation. Especially in the case of ancient authors whose biographies are barely known to us, this critical attitude ends up privileging reconstruction - for instance of the historical and biographical circumstances within which the author operated or of his or her intentions - instead of interpreting the text as it appears to us.

Along these lines, in the case of this mysterious praefatio, the most accredited interpretation is sustained by the effort of reconstructing Claudian's poetic career, presupposing a long series of details which are far from being obvious or historically founded. According to most scholars, we must read this preface as a passage in which Claudian is speaking about himself and his poetic activity: the sailing man represents the poet himself, who is ready to attempt a major undertaking, i.e. the writing of epic poetry with a mythological subject, which is traditionally conceived of as the highest poetic achievement. But, as I have suggested, this interpretation is problematic not only because the text contains not a single hint at comparison of any kind, or at any activity other than sailing, but also for two other reasons. First, this interpretation presumes that, prior to this poem, Claudian had been a panegyric poet. As some scholars have already observed, panegyric and epic are in late antiquity very tightly connected. Stephen Wheeler, for instance, contends that in Claudian's poem the tradition of heroic epic is subsumed within the panegyric genre: panegyric, Wheeler argues, is in fact "the culmination of epic tradition." ${ }^{8}$ Second, and more importantly, this interpretation while offering the advantage of allaying the anxiety for contextual and biographical reconstruction broadly characterizing the hermeneutics of Classics by providing an allegedly historical and 'objective' explanation - is actually based on an idée reçue, an absolute lack of information, and a massive amount of uncertainty. Nonetheless, and symptomatically, the editor of the poem in the Budé, Jean-Louis Charlet, leaves no room for doubt:

En claire, elle (scil. cette preface) signifie qu' après avoir écrit de petits poèmes (v. 5-6: navigation le long des côtes), puis de poèmes de moyenne importance (v. 7-8: traverse des

7 Felgentreu 1999, 163 exemplarily defines the solving of the allegory ("Auflösung der Allegorie") in the case of this praefatio as "redundant", as if allegory always needs to be "solved".

8 Wheeler 2007, 120, Ware 2004 and Pelttari 2014, 57 also emphasize the epic quality of Claudian's panegyric poetry. Others suppose that Claudian wrote De Raptu Proserpinae in an earlier stage of his career, in which case the reference would be to his carmina minora and compositions in Greek. See Guipponi-Gineste 2010, 20 (with relevant bibliography). 
golfes en s'écartant de la terre), le poète entreprend une oeuvre audacieuse (v. 9-12: navigation en haute mer qui affronte les tempêtes et les surmonte). ${ }^{9}$

To be sure, Charlet himself rightly notes that, even if everybody seems to agree with this reading of the praefatio, there is no scholarly consensus about the details and above all the chronology, which nonetheless seems to be the real preoccupation of many scholars. ${ }^{10}$ But again, despite the unavoidable divergences in evaluating single details, scholarly discussion is not about the text itself, but rather about Claudian, his intentions and the circumstances within which he conceived his poem. Yet the question "What might Claudian have wanted to say with this poem?" is not only unsolvable but also irrelevant to the interpretation. I would even go so far as to point out that, even if we could ever find external evidence somehow confirming the currently prevailing hypothesis that Claudian wanted to present his own poetic career in an allegorical form, this certainty would not solve the immanent ambiguity of the text, nor would it in itself actually be an interpretation at all, but rather a description of external factors and authorial intentions. And finally, even if we strongly believe that the reconstruction of Claudian's intentions is fundamental to interpreting the text, then we should at least acknowledge the obvious: in this preface Claudian himself clearly did not want to give any hint at, or establish any connection with, his own poetic career, or with the subject matter of the poem (the myth of Proserpina), or with any specific historical event. It is thus safer to argue that, whatever Claudian's intentions might have been, this ambiguous preface and more generally De Raptu Proserpinae avoids any reference to his own biography and to the immediate historical context. ${ }^{11}$

How, then, to read De Raptu Proserpinae (to echo the telling title of Charlet's article, "Comment lire le de raptu Proserpinae")? Of course, no interpretation is ever entirely stable, for it is in the nature of any hermeneutic act that it must always be ever-changing: there is no single access to the text, there is no single "how to read". A valid interpretation need not represent a dogma; instead we call it valid precisely because it invites being challenged, being put under scrutiny and in the end perhaps being undone by future critics.

9 Charlet 1991, XX, emphasis mine. In his 2008 edition Onorato (p. 13) accepts this interpretation without discussing it.

10 See Charlet 1991, XXI-XXVIII. Cf. Harrison 2016.

11 The eluding of the historical context within a poetic text might be identified as a characteristic of late antique texts. See Formisano, forthcoming. 
After having pointed to the ambiguous nature of the famous preface and having described the epistemic difficulties intrinsic to the kind of criticism which departs from ambiguity as a kind of enigmatic puzzle intentionally launched by the poet, in what follows I discuss the short carmen by taking seriously its very function as a preface, i.e. as a hermeneutic key to the entire epic: it is the preface which tells us how to read the De Raptu Proserpinae. To recall the definition by Gerard Genette at the opening of his famous Seuils, a paratext is "a fringe of the printed text which in reality controls one's whole reading of the text." 12 If we read the praefatio in this way, on the one hand we will perceive it as an organic part of the epic poem as a whole, but on the other we will be able to appreciate its constitutive ambiguity and to make sense of it - without feeling the urge to solve a puzzle by alienating it from the corpus of the poem proper and launching aleatory reconstructions of Claudian's original intentions, whatever they might have been. This preface not only functions as a paratext to the main poetic text, i.e. the mythological narration, but also represents a mise-en-abyme both of what a paratext in itself is, and of the very act of reading. It associates the reading of this poem with a narrative of displacement: there is a man who undertakes a voyage at sea and gradually distances himself from the mainland, and precisely this displacement is seen in the positive terms of an accomplishment rather than, for instance, of a loss. Within this narrative a clear tension but also a complementarity is established between land and water. As Genette notes at the beginning of his treatise, a paratext "constitutes a zone between the text and off-text, a zone not only of transition but also of transaction." ${ }^{13}$ More than any other aspect, the evident theme of the preface is transition, represented as a sea journey.

Moreover, as probably any reader immediately perceives, the preface needs to be read as an allegory itself. As mentioned above, this allegory has been interpreted by the majority of critics as an intentional camouflage crafted by Claudian himself in order to reveal to his readers that he is now presenting an epic poem, and that this represents a major achievement in comparison to his previous, allegedly less ambitious writings. Within this construction, it remains mysterious why Claudian should have felt it necessary to convey this very basic point by means of an allegory. On the other hand, the De Raptu Proserpinae itself, as is uncontroversially accepted, ${ }^{14}$ invites being read allegorically, although it per se is not an allegory but a mythological tale. This allegorical preface therefore perfectly fits within the epic project at large by offering a key to its interpretation,

12 Genette 1997, 2 (quoting Philippe Lejeune).

13 Genette 1997, 2.

14 See Charlet 2000 for a summary of different positions. 
but at the same time it stays outside of the mythic narration proper by implicitly emphasizing its own paratextual nature. As observed by Laura Jansen, a paratext is not only 'beside' or 'next to' (para) the text, but also an organic part of that text. In her words, "paratexts are neither fully attached to nor detached from the text, but they conform to a liminal zone between its inside and outside." 15

Although classicist readers - eager as they are to read their texts always in function of previous works, hunting for all possible intertextual references and allusions - might not be attracted by what the text itself has to say, displacement and rupture undoubtedly are the main topic of the preface and of the entire poem. ${ }^{16}$ This preface transfigures its own prefatory nature in an allegory, by vividly representing its own liminal condition along with a litoral narrative, represented by the tension between the mainland (litora summa) and the high sea (profundum), thus pointing to a displacement of meaning - as opposed to a literal narrative - and hence implicitly inviting an allegorical understanding of the preface and of the epic poem altogether. At the same time, this preface manifestly does not offer any single reference either to the epic which follows, or to the historical context, or to the author himself, so that, if we had found this little carmen separately from the corpus of the poem, we would not have been able to reconstruct that it belongs to the De Raptu Proserpinae. Aaron Pelttari comments that most late antique prefaces, and particularly those written by Claudian, "center upon the poet and his relation to the subject". He also contends that "Claudian's prefaces guarantee that his poems will be read within their original context." ${ }^{17}$ This is not, however, the case with this particular praefatio, which is perhaps unique within Claudian's oeuvre, since within it both the poet and the context are manifestly obscured, while, more importantly, what Pelttari calls "room for reading" - i.e. a proactive call to the readers to interpret - is implicitly exalted. ${ }^{18}$

Classicists are not friends of allegory, for it represents for them an apparently insurmountable epistemic obstacle, capable of powerfully shaking their hermeneutical practices that are usually oriented at reconstructing, through the text, broader cultural and historical contexts. Typically (as the story of the interpretation of this particular praefatio ever since the intrusive anonymous scribe in Sankt-Gallen exemplarily shows), as soon as they encounter an allegory, they try to "solve" it, i.e. to identify a stable meaning, supported by a precise contextual reading and the consideration of the author's Sitz im Leben. And yet, allegory is not a camouflage

\footnotetext{
15 Jansen 2014, 5.

16 See Formisano 2017, 220-227.

17 Pelttari 2014, 57.

18 Pelttari 2014, 72.
} 
concocted by the author in order to titillate the detective skills of his or her readers. But as modern discussions of allegory and allegoresis point out, allegory is defined by two characteristics above all. First, it produces its meaning through negation, since it constitutively denies what it presents, and second, it is self-reflexive, since it refers to itself and its own use of verbal signs. ${ }^{19}$ Accordingly, instead of finding a "solution" to an allegorical enigma, it might be more rewarding for a literary interpretation to consider allegory as such, i.e. as an approach which emphasizes the ambiguity sustaining the poem as a whole. As recently pointed out by Fredric Jameson in his book Allegory and Ideology, allegory is often misused to refer to a "oneto-one narrative" which establishes a neat correspondence between two levels of signification. This two-level system is according to Jameson "the mark of bad allegory," while "genuine allegory does not seek the 'meaning' of a work, but rather functions to reveal its structure of multiple meanings, and thereby to modify the very meaning of the word meaning." 20

Most scholars have considered both prefaces of Claudian's major epic poem as texts which are readable separately from the poem. This critical tendency is based on the fact that neither preface, in content or in form, shows a connection to Proserpina's myth itself or to its epic hexametric form. They are mostly read as external textual occasions on which Claudian describes his own poetic career (first praefatio) and compares himself to Orpheus who after a long break returns to his activity as a singer in order to celebrate Hercules' labors (second praefatio). Christine Schmitz has convincingly insisted on the necessity of involving both prefaces in the interpretation of the poem as a whole by identifying a motif which runs through the entire poem: the civilizing role of ars upon untamed nature. ${ }^{21}$ Moreover, Schmitz contends that Claudian does not distance his new epic from his previous panegyric poems, as most scholars imply, but instead that the poet compares himself to Orpheus, who in the second preface is presented as the admirer of Hercules' labors. In this sense, Schmitz is interested in shedding light not only on the internal cohesion of this text, i.e. between the prefaces and the body of the poem itself, but also between Claudian's epic and panegyric projects. ${ }^{22}$ In doing so, she implicitly emphasizes the fundamental coherence of Claudian's persona who is able to combine different literary genres under the same poetics in an organic manner.

19 See Kablitz 2016, 15.

20 Jameson 2019, 10.

21 Schmitz 2004.

22 On internal cohesion within Claudian's oeuvre, see also Bureau 2009 and, in greater detail, Guipponi-Gineste 2010, who affirms that all works by Claudian, including the carmina minora, are part of a "projet poétique d'une grande cohérence" (10). 
Here I am less interested in identifying a conceptual coherence between the De Raptu Proserpinae and Claudian's other works. Rather, my intention is to shed light on the fundamental role which the first preface plays for the entire poem; for this, I would argue, provides a key to the interpretation of the epic poem as an allegory. For the majority of critics, allegory ends up being a sort of superficial disguise for a certain deeper meaning. ${ }^{23}$ While not denying the communis opinio, Pelttari adds a significant element to the interpretation by identifying the invention of the first boat (which he also reads as a reference to Jason) as a "transgressive act" paralleling the epic project of Claudian himself: "The figure of the first mariner makes a problem of originality rather than of conventionality." 24

If we proceed with a consideration of the text itself - i.e. on the one hand leaving aside the tentative reconstruction of Claudian's intentions, whatever those might have been, and on the other hand renouncing the search for a single and precise meaning beyond the allegory represented by Proserpina's myth - we will discover that the preface can be read as an invitation to consider ambiguity as a constitutive aspect of this specific poem and perhaps, more broadly, of late antique poetics. What strikes the reader is the apparent banality of the preface's content, which stands in powerful contrast with the highly elaborate style of the elegiac couplets. More particularly, one word stands out both in its meaning and in its position: the present participle legens, located precisely in the middle of the twelve-line preface. Although no other commentator has noticed this, this word sustains and gives meaning to the preface and therefore, I suggest, to the entire poem. In it, also by virtue of its central position, the reader can perceive the profound ambiguity following which he or she can approach the whole poem: litora summa legens (v. 6) "skirting the edge of the shores," after which the man who is sailing feels free to move away from the coast and spread his sails to the winds. Moreover, the positioning of legens at the very center of this carmen and the end of the pentameter adds a performative quality to its meaning: until now the sailor is legens, but from now on he no longer "skirts/reads" the coast. If we read this text spatially, i.e. visualizing it in terms of space, legens represents a sort of border, beyond which something different begins. The sailor is thus an allegory not of the author but of the reader, who experiences a profound change in his or her approach to the text. Thus legens is a syllepsis, i.e. a word within which different meanings "fall together", which is arguably the single most characteristic figure for what we call ambiguity. The understanding of syllepsis I am referring

23 See Charlet 2000 for a mise au point of the various hermeneutic strategies adopted by scholars; approaches have not significantly changed since then.

24 Pelttari 2014, 7. 
to derives from literary theorist Michael Riffaterre, who in his landmark 1980 article "Syllepsis" argued that this figure and the ambiguity which derives from it strongly mark literary discourse as such.

In this article, Riffaterre prefers the term "presuppositions" to intertextual references:

The text is not simply a sequence of words organized as syntagms but a sequence of presuppositions. In literary writings every lexical element is the tip of an iceberg, of a lexical complex whose whole semantic system is compressed within the one word that presupposes it. To put it otherwise: the literary text is a sequence of embeddings with each significant word summarizing the syntagm situated elsewhere. ${ }^{25}$

In our case, the word legens, emphasized by its central position and at the end of the pentameter, while superficially meaning "skirting", evokes its apparently absent meaning, i.e. "reading". And precisely this possibility of perceiving other apparently absent meanings within a certain word produces ambiguity, which, according to Riffaterre, is "the kind of obscurity that prevents the reader from quite discerning which of a word's pertinent meanings are equally acceptable in context." ${ }^{26}$ Therefore, if we accept that legens, as a syllepsis, has the meaning not only of "skirting" but also of "reading", which is precisely what a reader does in the moment of perceiving this very text - and also in the moment of perceiving the possibility of its inherent ambiguity - then we may interpret this preface as an instantiation of the very act of reading and, consequently, of the constitutive ambiguity which always derives from it.

Elsewhere I have argued that the De Raptu Proserpinae strongly thematizes disjunction from literary tradition, by producing a new literary space, allegorized by the underworld; ${ }^{27}$ I read the mainland (litora summa, v. 6) from which the solitary sailing man is departing as the landscape of the classical poetic tradition. ${ }^{28}$ In the present essay I would like to add a further layer of complexity to my previous thoughts by proposing that this preface can be read as an allegory of allegory, or perhaps as an allegory of reading, to allude to the title of Paul de Man's famous book. ${ }^{29}$ As we have seen, the allegorical potential of the preface, as well as of the

25 Riffaterre 1980, 627 (emphasis added).

26 Riffaterre 1980, 628.

27 Formisano 2017, 227.

28 For a similar reading see also Pelttari 2014: "the image of poetic production as a voyage is common throughout Latin poetry, but this allegory can also be read as referring to the tradition" (7, emphasis added).

29 de Man 1982. 
poem in its entirety, is universally accepted, but rarely discussed or problematized as such. Charlet insists on the contemporary Christian readership and its "habitudes de lecture", ${ }^{30}$ whereas Bruno Bureau emphasizes the commonalities between pagan and Christian authors in the use of allegory and allegoresis (Claudian and Prudentius). ${ }^{31}$ Among others, Hellenist Gianfranco Agosti insists on the necessity of applying allegoresis to the reading of late antique texts at large, both prose and poetry..$^{32}$ And as I myself have argued elsewhere, although today allegory is marginalized on our current hermeneutic horizon, it deserves to be re-activated for the interpretation precisely of late antique texts. ${ }^{33}$

Returning to our text, reading legens as "reading", the process of distantiation from the edge of the shores (litora summa, v. 6) becomes the distantiation from the literal/littoral meaning, where seafaring on the open sea (pelagus, v. 11) and the act of following the sky (caelumque secutus, v. 11) become an allegory of allegoresis itself, without however promoting any stable meaning other than itself. Claudian's preface marks its distance from the text by virtue of its formal aspects (elegiac couplets opposed to the hexametric body of the epic proper), and of its non-relatedness to the topic of the poem, as well as by thematizing spatial distance itself (from the coast towards the high sea).

At the same time it offers its readers the hermeneutical key to the poem itself: the story of the abduction of Proserpina cannot claim any particular theological authority any more. Therefore it inherently requires being read allegorically. Charlet, in his programmatic article on "Comment lire", suggests some possibilities, insisting above all on a political and a cosmological allegory able to satisfy both Christian and pagan readers. ${ }^{34}$ By establishing this "one-to-one" allegory or allegories - Charlet follows the common critical tendency that avoids the danger of arbitrariness which in his mind casts a shadow on every allegorical reading. But the kind of allegoresis to which this text seems to invite its readers is far from establishing a simple equation between a literal and an allegorical meaning; this equation would be a "bad allegory" in Jameson's terms. Rather - and more simply perhaps - it manifests the loss of a stable significance of the classical tradition.

The thematization of this loss of significance characterizes the poem in its fundamental structural aspects as well. The textuality of De Raptu Proserpinae

30 Charlet 2000, 186.

31 Bureau 2009, 5 n. 13.

32 Agosti 2005.

33 Formisano 2018.

34 Charlet 2000. 
constantly evokes a process of distantiation and interruption. Many passages exemplarily represent break and interruption. In Book 1 Sicily is represented in its violent separation from continental Italy (141-147):

Trinacria quondam

Italiae pars una fuit, sed pontus et aestus mutavere situm. Rupit confinia Nereus victor et abscissos interluit aequore montes 145 parvaque cognatas prohibent discrimina terras.

Nunc illam socia ruptam tellure trisulcam opposuit natura mari.

Trinacria was once a conjoined part of Italy, but sea and time have changed the lie of the land. Victorious Nereus burst his boundaries and washed between the severed mountains with his waters, and a small division keeps apart these kindred countries. Now Nature has set against the sea that three-pronged island that is broken from its related ground.

At the end of Book 1 Proserpina is portrayed at the moment when her work at weaving a tapestry is interrupted by the arrival of the three goddesses who will eventually attract her outside of the palace: imperfectumque laborem / deserit (271-272). Interruption is the main theme of the preface of Book 2, represented by Orpheus who returns to his poetic activity after a long break. But by displaying interruption as a motif, the preface also performs an interruption in itself, since it breaks the narration between Books 1 and 2, and at the same time recalls Proserpina's imperfectus labor. As convincingly noticed by Schmitz, the representation of Orpheus as an artist parallels that of Proserpina herself. ${ }^{35}$ Book 2 contains the central scene of the raptus, which is described in terms of violent rupture (151-213). And again in Book 3, Ceres, while desperately looking for her daughter, enters the empty palace where she was hidden and finds her unfinished work in the process of being completed by an audax aranea with her "sacrilegious text" (153-158):

foribusque reclusis,

dum vacuas sedes et desolata pererrat

atria, semirutas confuso stamine telas

atque interruptas agnoscit pectinis artes.

divinitus perit ille labor, spatiumque relictum

audax sacrilego supplebat aranea textu.

35 Schmitz 2004, 36. 
Opening the doors, as she passed through the empty rooms and deserted halls, she recognized the half-ruined weaving with its disordered threads and the work of the shuttle that had been broken off. That wonderful task of the goddess had gone to waste and the bold spider was completing the gap left behind with her sacrilegious web.

But the most impressive sign of interruption is of course the fact that the poem was never completed by its author. We can speculate, if we like, that he suddenly died and thus was not able to put an end to his work. But, precisely as in the case of Proserpina's weaving, nothing prevents us from attributing an aesthetic significance to the fact of the poem's lack of completion, fully independently of the intentions of Claudian. ${ }^{36}$

To conclude, the allegory represented by this highly ambiguous preface must be taken seriously in itself; it represents the hermeneutic key to the entire poem. No other truth is indicated by the poet; his allegory is not a one-to-one symbolism where every literal element has an allegorical correspondent. Rather, this allegory represents allegory itself, the struggle with the classical poetic tradition, as well as, more generally, the eternal search for a meaning located outside the text. My hermeneutic strategy on the one hand recognizes the liminality of the praefatio as a paratext, but differently from the usual biographical approach, which banalizes the inherent ambiguity by trying to solve it, and reads it as wholly separated from the poem itself, my reading re-establishes the role of the praefatio for the understanding of the entire poem as an allegory. Read this way, this preface becomes a superb manifesto of late antique poetics for a number of reasons above all because it offers the key to the interpretation of the entire poem, by showing its function as a program of poetic hermeneutics. As has recently been argued, late antiquity is the age of the preface which becomes a means of increasing the distance between the author and his/her text. ${ }^{37}$ This particular preface also allegorizes the distantiation from the classical tradition, represented by the mythological subject matter (the tale of Proserpina), which cannot be read otherwise than as something else. To this "something else" we certainly can attribute some particular meaning - cosmological, political, ritual - but we must keep in mind that no firm interpretation is offered by the text itself, which along with all other possible meanings also signifies its own radical and ineffable ambiguity.

36 Schottenius Cullhed 2019 interprets interruption in this poem as a typical feature of the language of trauma, particularly as related to sexual violence.

37 McGill 2017. 


\section{Bibliography}

Agosti, Gianfranco (2005), “Interpretazione omerica e creazione poetica nella tarda antichità”, in: Antje Kolde et al. (eds.), Koryphaio andri. Mélanges offerts à Andre Hurst, Geneva, 19-32.

Albrecht, Michael von (1989), “Proserpina's Tapestry in Claudian's De Raptu Proserpinae: Tradition and Design", ICS 14, 383-390.

Bureau, Bruno (2009), “Figures de poètes chez Claudien”, in: Perrine Galland-Hallyn/Vincent Zarini (eds.), Manifestes littéraires dans la latinité tardive: poétique et rhétorique, Paris, 51-70.

Charlet, Jean-Louis (1991), Claudien, Oeuvres: Tome 1. Le rapt de Proserpine, Paris.

Charlet, Jean-Louis (2000), “Comment lire le de raptu Proserpinae de Claudien”, REL 78, 180-194.

Felgentreu, Fritz (1999), Claudians praefationes: Bedingungen, Beschreibungen und Wirkungen einer poetischen Kleinform, Stuttgart/Leipzig.

Formisano, Marco (2017), “Displacing Tradition. A New-Allegorical Reading of Ausonius, Claudian and Rutilius Namatianus”, in: Jaś Elsner/Jesús Hernández Lobato (eds.), The Poetics of Late Latin Literature, 207-235.

Formisano, Marco (2018), "Fragments, Allegory, and Anachronicity. Walter Benjamin and Claudian", in: Sigrid Schottenius-Cullhed/Mats Malm (eds.), Reading Late Antiquity, Heidelberg, 33-50.

Formisano, Marco (forthcoming), "Seeing Double: The Contemporary and the Immemorial in Claudian and Colluthus", Ramus.

Jameson, Fredric (2019), Allegory and Ideology, London.

Jansen, Laura (ed.) (2014), The Roman Paratext: Frame, Texts, Readers, Cambridge.

Kablitz, Andreas (2016), Zwischen Rhetorik und Ontologie: Struktur und Geschichte der Allegorie im Spiegel der jüngeren Literaturwissenschaft, Heidelberg.

Genette, Gérard (1997), Paratexts. Thresholds of Interpretation, trans. by J.E. Lewin, Cambridge.

Gruzelier, Claire (1993) (ed.), Claudian. De Raptu Proserpinae. Edited with Introduction, Translation and Commentary, Oxford.

Guipponi-Gineste, Marie-France (2010), Claudien: poète du monde à la cour d'Occident, Paris.

Harrison, Stephen (2017), “Metapoetics in the Prefaces of Claudian's De Raptu Proserpinae", in: Jaś Elsner/Jesús Hernandez Lobáto (eds.), The Poetics of Late Latin Literature, Oxford, 236-251.

Hinds, Stephen (2012), Displacing Persephone: Epic between Worlds, Housman Lecture, London.

Man, Paul de (1979), Allegories of Reading. Figural Language in Rousseau, Nietzsche, Rilke, and Proust, New Haven.

McGill, Scott (2017), “Rewriting Ausonius”, in: Jaś Elsner/Jesús Hernandez Lobato (eds.), The Poetics of Late Latin Literature, Oxford, 252-277.

Onorato, Marco (2008), Claudio Claudiano, De Raptu Proserpinae, Naples.

Pelttari, Aaron (2014), The Space That Remains. Reading Latin Poetry in Late Antiquity, Ithaca, NY. Riffaterre, Michael (1980), "Syllepsis", Critical Inquiry 6.4, 625-638.

Schmitz, Christine (2004), “Das Orpheus-Thema in Claudians De raptu Proserpinae”, in: WiduWolfgang Ehlers/Fritz Felgentreu/Stephen Wheeler (eds.), Aetas Claudianea, Munich/ Leipzig, 28-56. 
Schottenius Cullhed, Sigrid (2019), “Proserpina in Pieces. Claudian on Her Rape”, Ramus 48, 1 , 82-94.

Ware, Catherine (2004), “Claudian: The Epic Poet in the Prefaces”, in: Monica Gale (ed.), Latin Epic and Didactic Poetry: Genre, Tradition and Individuality, Swansea, 181-201.

Ware, Catherine (2011), “Proserpina and the Martyrs: Pagan and Christian in Claudian's De Raptu Proserpinae”, in: Elizabeth Mullins et al. (eds.), Listen, O Isles, unto Me: Studies in Medieval Word and Image in Honour of Jennifer O'Reilly, Cork, 16-27.

Wheeler, Stephen (2007), “More Roman Than Romans of Rome: Virgilian (Self-)Fashioning in Claudian's Panegyric for the Consuls Olybrius and Probinus", in: John H.D. Scourfield (ed.), Texts and Culture in Late Antiquity. Inheritance, Authority, and Change, Swansea, 97-134. 
